\title{
The Analysis of Coalition Parties' Election Programme Fulfillment: Czech Case Study
}

\author{
Ondřej Kuba $^{1}$, Jan Stejskal ${ }^{2}$ \\ University of Pardubice, Faculty of Economics and Admistration E-
}

\begin{abstract}
In multi-party democratic systems, where there is no absolute majority, the political parties are forced to cooperate. The cooperation is built on negotiations that result in several side effects including also concessions and compromises in the program. This analysis focused on the fulfillment of the coalition party promises in the Czech Republic, specifically on Prime Minister Bohuslav Sobotka's government. The input data of the research consisted of a prepared set of testable political promises from the pre-election programs of selected political parties. The promises were compared with the contents of the coalition agreement, the government's policy statement. It was found that coalition political parties selected by the government within the framework of coalition cooperation managed to enforce approximately $36 \%$ of their election promises. At the program level, $24 \%$ of promises were enforced. In areas that increase the personal budget of voters, government political parties have pushed $76 \%$ of promises. Regardless of their cooperation, they made approx. $52 \%$ of the election promises during the parliamentary term. The dominant party of the government was the CSSD.
\end{abstract}

Keywords: Coalitions, government, public choice, pledges, elections

\section{Introduction}

The public choice theory considers Political parties and politicians to be rational actors whose aim is to maximize their own benefit (Volejnikova, 2005). According to Strom (1990), this can represent, for example, gaining important political positions, reaching the highest possible number of voters, or enforcing a certain policy. Wolinetz (2002) points out, however, that in practice, political parties focus on at least two of these objectives. For example, parties cannot promote policy-enforcement without enough representative in the legislature. Additionally, office-seeking and vote-seeking parties cannot be successful without a political program that addresses voter's needs. 
It is clear from the above that designing, and implementation of political programs are important criteria in the long-term success of political parties. This assertion is supported by Budge and Hofferbert (1990), who claim that parties with a successful electoral program will form a government and be motivated to program

implementation. Parties may do so in relation to not only by the moral aspect, but also a concern about the results of the next elections. These concerns can be considered justified because, according to Zubek and Klüver (2015), the degree of fulfillment of the program offers voters a benchmark to assess the cabinet and thus provides the possible electoral advantage of governing parties in the elections.

The success of political parties in promoting their programs and delivering on their election pledges is largely dependent on the distribution of political forces. In bipartisan parliamentary systems, in which political parties have an absolute majority of seats in the parliament, the parties usually fulfill more electoral pledges than in pluralist parliamentary systems which constitute the foundation of the argument of this current paper. In the US, $79 \%$ of pledges were fulfilled by the government in the reporting period (Pomper \& Lederman, 1980). Also, in Canada, the government fulfilled $71.5 \%$ of pledges (Rallings, 1987) as well as in the UK, more than $80 \%$ (Royed, 1996). In pluralist systems, political parties are bound to work more closely with other parties and are unable to enforce their programs to such an extent. This is evidenced by research on the pledges of political parties in Ireland, where two governmental parties met at least partially $76 \%$ and $66 \%$ of their commitments in the reporting period, but only $45 \%$ and $47 \%$ of commitments were fully met in actual sense

(Costello \& Thomson, 2008). The reason for the low level of fulfilling of pre-election pledges is the results of coalition bargaining. The parties had to make several concessions and compromises in the program. In this example, the content of the program statement of the coalition government was different from the originally promoted priorities of individual political entities in the pre-election period.

The process of political negotiation has been the subject of political and economic research. Based on exploring the behavior of political entities in the negotiations, the socalled coalition theory emerged, which builds on game theory and assumes the rational behavior of all negotiating actors. Luebbert (1983) believes the coalition bargaining is much more important than the results of public choice. The results of bargaining are often different from the results of the public choice. This is evidenced, for example, by the 
results of the 2010 elections to the Chamber of Deputies of the Czech Republic (Stegmaier, Vlachová, 2011). At that time, the winning party was not represented in a coalition government (with the majority).

Strøm and Nyblade (2009) generally define coalitions as groups of individuals cooperating to promote common interests. Specifically, politicians are united to lead the government to transform a wide range of social requirements into public policies. In multi-party democratic systems where no party has a majority, this action is considered significant. According to Pedersen (2011) in these systems, policy influence comes at a cost to the parties' preferred policy. Political parties are not only interested in the realized policy, but also in the form of cooperation or division of offices because individual ambitions of politicians are an important determinant in the negotiation process (Budge and Laver, 1986). According to Strøm and Müller (1999), political parties in the joint government do "the business" (the logrolling) because they have different preferences across a wide range of issues and will seek to ensure maximum political, official and electoral benefits for themselves. The parties will be willing to make a compromise in the less preferred issues and will be uncompromised in the more preferred issues.

Success in enforcing the pre-election programs of political parties to the coalition program is dependent on several factors. For example, Peleg (1981) and Deemen (1989) mentioned the important role of the dominant player - the party with the largest number of representatives in Parliament. This political party in practice cannot practically be excluded. Moreover, if this party is centrally oriented, the final government policy will be identical to the policy of this party (Crombez, 1996). According to Laver (1998), it should not be forgotten, the importance of small political parties, which may have a strong expressive position, since without them an absolute majority would not be formed in Parliament. Such parties may extort other parties.

Institutional requirements for the formation of the government also greatly influence the political negotiations. For example, Strøm, Budge and Laver (1994) paid attention to the various constraints occurring in European states. One of the important institutional constraints of coalition formation is the designation of a political party, which will lead negotiations on the coalition. Baron (1991) has shown that this commissioned political party gains a competitive advantage in the strategic choice of a coalition partner. It can only offer cooperation to those of its own choosing. Bäck, Debus and Dumont (2011) believe that the designated party will select partners based on program similarity. Axelrod (1970) has the same opinion and adds that political parties will try to prevent high 
bargaining costs by forming coalitions from similarly ideologically grounded parties. Such coalitions can be very stable in cooperation, but their possible rivalry in the election period cannot be overlooked. Despite advocating a common ideology, the parties are trying to win the same voter at this time, and according to their motivation, they adjust their strategy (Downs, 1957).

An equally important factor that gives political parties a competitive advantage is a division of offices. For example, according to Warwick (1996) government policy is determined by the political party that controls the Treasury, as it decides which spending programs the government will financially support.

However, political parties are trying to prevent these abusive practices by various control mechanisms. For example, Thies (2001) states that the parties use political deputies appointed to coalition partner ministries. Similarly, according to Pukelis (2016), the chairpersons of parliamentary committees also carry out the control work.

All these factors affect the success of political parties more or less in the enforcement of their program. The aim of this paper is to analyze the situation of political parties in Bohuslav Sobotka's government, which concerns political promises and declarations. The paper will evaluate how many promises from the party's electoral programs had become part of the government program statement and how many of them had been successfully completed. The partial goal is to check whether the CSSD - as the winning party and the party dominating in the government - implemented the comparative advantages according to the assumption of Baron (1991).

\section{Methods}

The analysis of election pledges fulfilment will be based on the commitment approach defined by Royed (1996). This approach was used for analysis of electoral programs in studies by, for example, Schermann and Ennser-Jednastik (2012), Naurin (2014) or Thomson et al. (2017), and assumes the pledge of the party as a unit of analysis obliging the party to take action or produce a results that can be objectively assessed to meet or fail. Royed's potential pledge includes a commitment phrase (we will "push", "propose", "support", "secure", "provide", etc.), and a goal or policy to which the party commits.

With these methodological procedures we analysed the election programs of the CSSD (CSSD, 2013), KDU-CSL (KDU-CSL, 2013), ANO 2011 (ANO, 2013) and the government policy statement, which were coalition parties in Bohuslav Sobotka's 
government of (2014-2017). The primary data set (page pledge set) has been modified as follows:

- Statements by political parties that are not clearly defined by Royed (1996), will be transformed into this format. Long pledges will be made in shortened form, declarations of political parties containing more results

will be divided into more partial pledges and additional knowledge will be added to ambiguous pledges.

- If the political party's declaration contains more than one result (in one sentence), the pledges will be divided.

- Only pledges that can be assessed for compliance or non-compliance will be analysed. If its performance exceeds the electoral period under review, it will not be included in the analysis. Similarly, those that are not binding, measurable, specific, unambiguous will be excluded.

- Any pledge whose fulfilment is not dependent on the government's decision, but for example in the competence of territorial and professional selfgovernments or based on European Union legislation, will not be included in the data set. Pledges in the preparation of various strategies and concepts that are produced by the public administration will also be excluded.

It follows from the above mentioned that a testable pledge must be binding, measurable, specific, time-bound, unambiguous and must be the result of government action. Successful fulfilment of such a defined pledge will manifest itself, on the one hand, in the size or structure of public budgets, or in the legislative obligation to fulfil something or to claim something. Any legislative change (introduction, amendment, revocation) will be considered as compliance with the legislative pledges, although the party's agenda may include a vague notion of "fair", "complete", and so on.

Pledges will also be considered fulfilled, for example, by a resolution of the Constitutional Court (a case of a taxpayer returning a tax to a working pensioner) or by a law created by a previous government. Such point pledges are considered pledges of the status quo, which does not change anything but confirms the party's preference.

The data sets of the political parties' pledges will then be used for graphical presentation of the results and discussion. 


\section{Results}

Real electoral programs of political parties were modified according to the abovementioned methodological principles. This resulted in a target group containing 237 testable pledges ( 88 pledges of the CSSD, 62 pledges of the KDU-CSL, 87 pledges of ANO 2011). These pledges oblige political parties to change legislation, or to implement another concrete and objectively verifiable commitment. The overall success of political parties in negotiating a coalition agreement, expressed as the proportion of all pledges included in the coalition agreement to the total number of pledges in the party program, is presented in Figure 1 (Kuba, Stejskal \& Prokop, 2019).

Figure 1 - Share of pledges included in the coalition agreement.

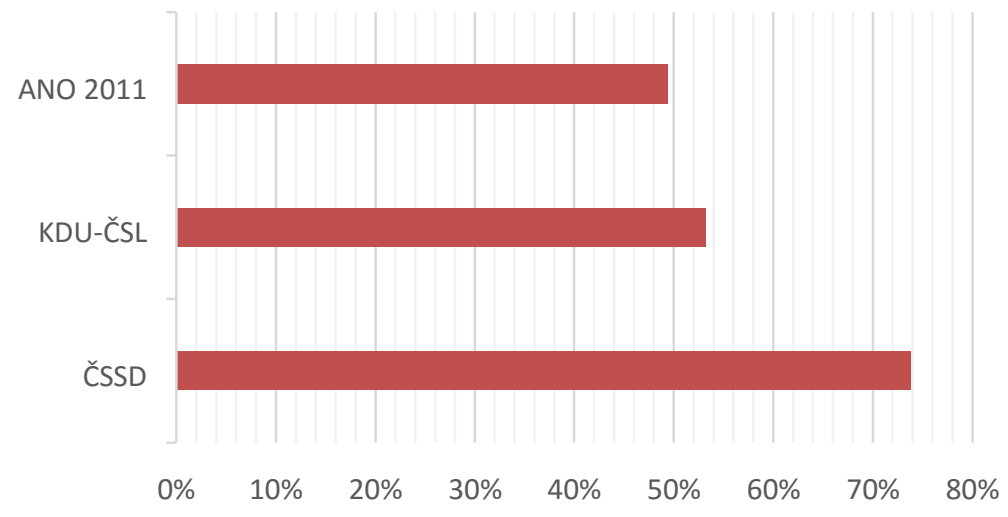

Source: authors' calculations based on the primary data

Figure 1 shows that the CSSD managed to enforce almost $74 \%$ of all tested pledges in the coalition agreement. Although the KDU-CSL had less than a quarter of the tested pledges - fewer than the other parties - it managed to push $53 \%$ into the coalition agreement. The fewest pledges in the coalition agreement were pushed through by ANO 2011, which only pushed $49 \%$ of all tested pledges from its pre-election program into the coalition agreement. The overall ratio of pledges included in the coalition agreement is as follows: CSSD $46 \%$, ANO $201131 \%$ and KDU-CSL $23 \%$. The coalition agreement was based primarily on the CSSD program and confirmed the strong bargaining position of the party that sets up the coalition.

The negotiation process does not end with the formation of a coalition agreement. Furthermore, the coalition parties must be able to jointly enforce the pledges made to the 
treaty. Figure 2 shows the proportion of coalitions of fulfilled pledges, broken down by party from whose programs the pledges came.

Figure 2 - Share of fulfilled pledges from coalition agreement.

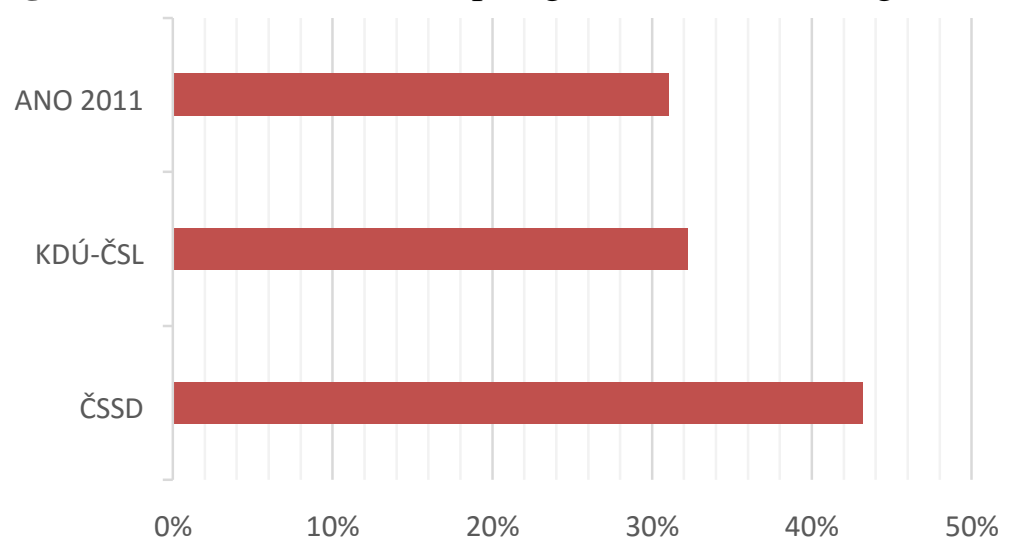

Source: authors' calculations based on the primary data

The government coalition pushed through a total of 85 of the 141 tested pledges (60 $\%)$. The individual political parties had a relatively low success in promoting election pledges. The CSSD has pushed 38 of the 88 pledges (43\%) into coalition cooperation over the entire term. KDU-CSL pushed 20 out of 62 pledges (32\%) and ANO 2011 only 27 out of 87 pledges $(31 \%)$. The order of successfully implemented pledges based on the programs of the parties is the same as the order of the parties in the number of pledges entered into the coalition agreement. Most pledges were based on the CSSD program, followed by ANO 2011 and KDU-CSL.

The results of the analysis show that the political parties forming the coalition have realized their election pledges in the same proportion as they were enforced in the coalition agreement. This means that the coalition has been balanced in the enforcement of the program and there has been no significant promotion of goals from one party program to the detriment of the other party. This balance probably stems from the programmatic intersection of the parties.

A more significant document than a coalition agreement may be a government program statement. This is based on a coalition agreement, but is limited to the government's priorities, which should be met by individual ministries during the public choice. The analysis shows that political parties have made fewer pledges to the 
government program statement than to the coalition agreement - in total, 91 from 237 pledges (38\%). CSSD added to the government statement $42 \%$ of the pledges. KDUCSL pushed $39 \%$ of pledges into the program statement (24 out of 62) and ANO 2011 pushed $35 \%$ of pledges (30 out of 87 ). The order of success of the parties in promising in the program declaration is identical with the order of the parties in the success of realizing pledges in the coalition agreement.

However, the representation of the parties' pledges in the government program statement is even more than in the case of the coalition agreement, as the CSSD's pledge ratio is not so significant compared to the other parties. The overall success of the parties in fulfilling the tested pledges included in the government's policy statement is presented in Figure 3. The graph shows that the most realized pledges from the government program statement came from the CSSD program $(27 \%), 23 \%$ of the ANO 2011 program and 21 $\%$ of the election pledges were fulfilled for the KDU-CSL.

Figure 3 - Share of realized pledges from government program statement.

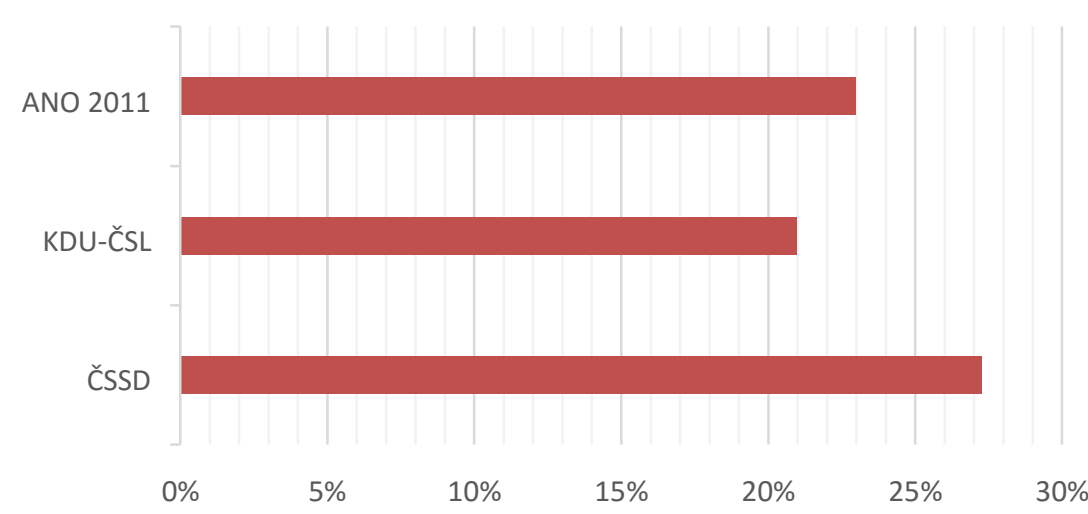

Source: authors' calculations based on the primary data

As in the case of the coalition agreement, there was no extreme realization of pledges from only one political party. The parties' pledges are almost the same as the pledges made by the parties to the government program statement.

Coalition political parties may in some cases vote in Parliament with parties other than those they are in coalition with. This collaboration can work, for example, on an adhoc basis. The purpose of such party behavior is to push through the electoral program to the maximum extent. Figure 4 shows the ratios of the fulfilled pledges against all pledges 


\section{$2^{\text {nd }}$ International Conference on Research in BUSINESS, MANAGEMENT AND FINANCE}

of the parties (to this amount we count also the pledges that were not included in coalition agreement and government program statement).

Figure 4 - Share of fulfilled pledges of coalition parties.

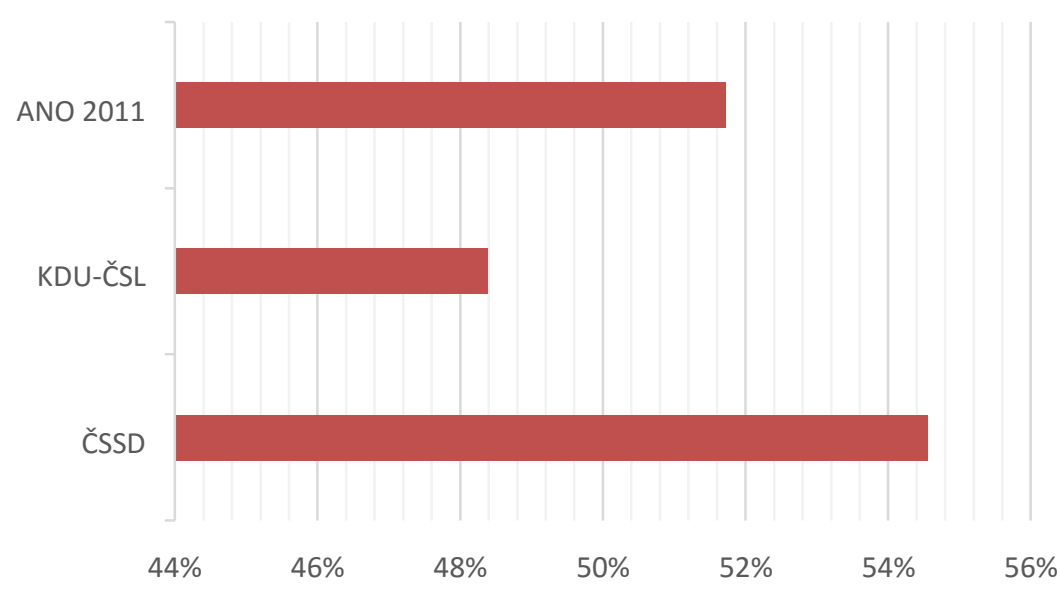

Source: authors' calculations based on the primary data

It is clear from Figure 4 that governmental political parties in Parliament have been able to push through about half of their electoral program pledges, regardless of whether their pledges are part of a coalition agreement or whether they pursue a coalition or opposition program. The majority of pledges outside the coalition agreement were managed by ANO 2011 (approximately $20 \%$ ).

In the final part of the analysis, an evaluation of the pledges' fulfilment is realized. Just those pledges which clearly had a positive influence on the voter's budget were analyzed. These pledges include reducing the tax burden on voters in the form of various tax reliefs, reducing V.A.T, raising minimum wages, abolishing doctor's fees etc. The analysis is based on a fiscal choice (the voter does not only choose according to preferences but also according to the amount of the pension and the tax system). The prerequisite, therefore, is that the parties will endeavor to enforce measures that will increase their popularity by the next election. Fulfilment of these pledges should be a clear priority for the parties, as it directly affects voters. Figure 5 shows the fulfilment of these selected pledges. 


\section{$2^{\text {nd }}$ International Conference on Research in BUSINESS, MANAGEMENT AND FINANCE}

Figure 5 - Fulfilled pledges with positive impact on personal income.

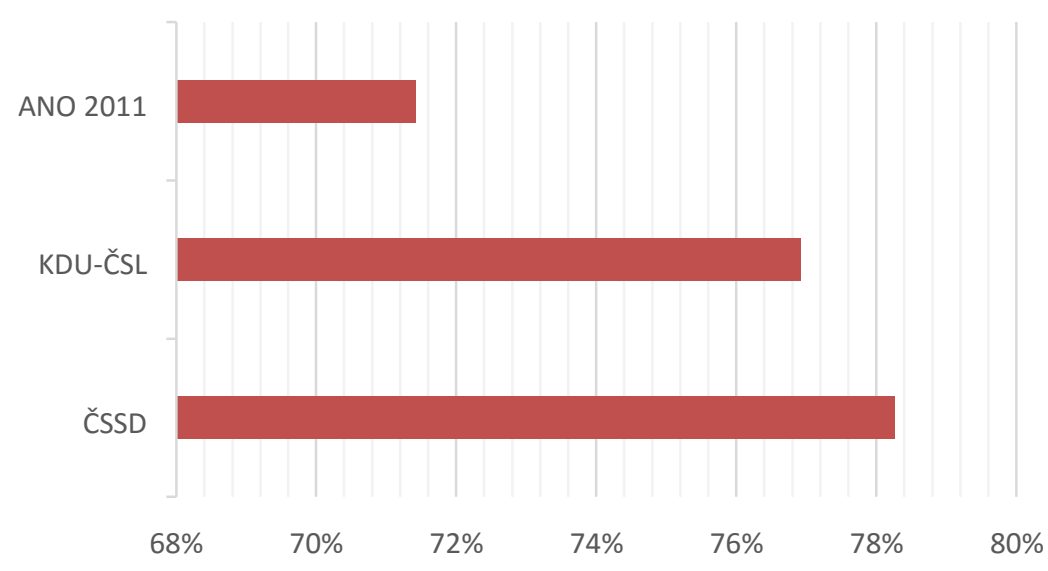

Source: authors' calculations based on the primary data

Together, the political parties made 50 pledges in the areas of tax relief, tax cuts, salary growth, pension growth, minimum wage increases, and so on. Out of these, 23 pledges were made by the CSSD (fulfilled 18 pledges; $78 \%$ ). The KDU-CSL proposed 13 changes and completed 10 (77\%). ANO 2011's electoral program contained 14 pledges, of which $10(71 \%)$ were pushed forward. Thus, this is the evidence that political parties are primarily seeking to promote political goals that will give them voter support. While in total, the parties managed to push about half of their program, they have pushed around three-quarters of their programs in this area.

\section{Conclusion}

This paper analysed the fulfilment of selected pledges of coalition political parties in the government of Bohuslav Sobotka (2014-2017). The objective of the analysis was to demonstrate the extent to which political markets distort the formation of coalitions. The parties must make several concessions and compromises in the formation of coalitions, and this behaviour can be considered a voter scam. They elect parties based on electoral pledges, which the political parties will eventually revise in the coalition negotiations and will not even include a substantial part of the government program.

The political parties forming Bohuslav Sobotka's government only enforced about 50 $\%$ of their program in the coalition agreement (73\% for the CSSD). In the government's program statement, 35-42 \% of parties' election pledges were included. Just 20-27\% 
them were fulfilled with the government's cooperation. The strongest party in promoting pre-election pledges was clearly the CSSD, which was able to push through the most pledges from all parties (both to the coalition agreement and to the government program statement). The reason for its success is probably its negotiator status, as the party won the election, formed the government, and had the most ministerial posts through which it could pursue its own policy.

Political parties, regardless of coalition cooperation, have managed to meet approximately $50 \%$ of all their pledges over the entire parliamentary term. With pledges that can be considered significant to voters, as they have a positive impact on personal budgets, the success in fulfilment of the pledges was higher. The parties have fulfilled more than $70 \%$ of the pledges.

The lack of analysis is a significant reduction in the data set, as political parties could eventually make more pledges from their program. However, verifying all the pledges would not be realistic, because for some pledges there are no benchmarks against which performance can be evaluated, or the verification would require additional evaluation criteria. However, the voters themselves are not able to evaluate all parties' pledges in the process of choosing and therefore the commitment approach used can be described as enough and meaningful.

\section{Funding}

This paper was supported by the Student Grant Competition (grant no. 18) of University of Pardubice in 2019.

\section{References}

ANO. (2013). Resort program. Retrieved from https:// www.anobudelip.cz/cs/o-nas/program/volby-2013/resortni-program/

Axelrod, R. M. (1970). Conflict of interest: a theory of divergent goals with applications to politics. Chicago: Markham Pub. Co.

Bäck, H., Debus, M., \& Dumont, P. (2011). Who gets what in coalition governments?

Predictors of portfolio allocation in parliamentary democracies. European Journal Of Political Research, 50(4), 441-478. doi:10.1111/j.1475-6765.2010. 01980.x 
Baron, D. P. (1991). A Spatial Bargaining Theory of Government Formation in Parliamentary Systems. American Political Science Review, 85(1), 137-164. doi: $10.2307 / 1962882$

Budge, I., \& Hofferbert, R. I. (1990). Mandates and Policy Outputs: U.S. Party Platforms and Federal Expenditures. American Political Science Review, 84(1), 111-131. doi:10.2307/1963632

Budge, I., \& Laver, M. (1986). Office Seeking and Policy Pursuit in Coalition Theory. Legislative Studies Quarterly, 11(4), 485-506. doi:10.2307/439930

Costello, R., \& Thomson, R. (2008). Election Pledges and their Enactment in Coalition Governments: A Comparative Analysis of Ireland. Journal of Elections, Public Opinion and Parties, 18(3), 239-256. doi:10.1080/17457280802227652

Crombez, C. (1996). Minority governments, minimal winning coalitions and surplus majorities in parliamentary systems. European Journal of Political Research, 29(1), 1-29. doi:10.1111/j.1475-6765. 1996.tb00639.x

CSSD. (2013). The election program of CSSD for election to Chamber of Deputies of the Parliament of the Czech Republic 2013. Retrieved from https://www.CSSD.cz/ke-stazeni/volebni-programy/volebni-program-CSSDprovolby-do-poslanecke-snemovny-parlamentu-ceske-republiky-2013/

Deemen, A. M. A. (1989). Dominant players and minimum size coalitions. European Journal Of Political Research, 17(3), 313-332. doi:10.1111/j.1475-6765. 1989.tb00196.x

Downs, A. (1957). An economic theory of democracy. New York: Harper

KDU-CSL. (2013). The election program 2013-2017. Retrieved from https://www.kdu.cz/o-nas/dokumenty/volebni-programy

Kuba, O., Stejskal, J., \& Prokop, V. (2019). The influence of political parties' coalitions on the electoral program fulfillment. In Proceedings from $13^{\text {th }}$ International Scientific Conference Public Economics and Administration 2019, September 1011, 2019. Ostrava: VSB-TU Ostrava.

Laver, M. (1998). Models of government formation. Annual Review of Political Science, 1(1), 1-25. doi: 10.1146/annurev.polisci.1.1.1

Luebbert, G. M. (1983). Coalition Theory and Government Formation in Multiparty Democracies. Comparative Politics, 15(2), 235-249. doi:10.2307/421678

Naurin, E. (2014). Is a Pledge a Pledge? Election Pledge Fulfilment in Comparative 
Perspective Using Sweden as an Example. West European Politics, 37(5), 10461064. doi:10.1080/01402382.2013.863518

Pedersen, H. H. (2011). Policy-seeking parties in multiparty systems: Influence or purity? Party Politics, 18(3), 297-314. doi:10.1177/1354068810382940

Peleg, B. (1981). Coalition formation in simple games with dominant players. International Journal of Game Theory, 10(1), 11-33. doi:10.1007/BF01770068

Pomper, G. M., \& Lederman, S. S. (1980). Elections in America: Control and influence in democratic politics. New York: Longman.

Pukelis, L. (2016). The role of parliamentary committee chairs in coalition governments: office and policy theses reconsidered. East European Politics, 32(2), 215-235. doi:10.1080/21599165.2016.1154844

Rallings, C. (1987). The influence of election programmes: Britain and Canada 19451979 (pp. 1-14). In I. Budge, I., Robertson, D., \& Hearl D. (Eds.), Ideology, Strategy and Party Change: Spatial Analyses of Post-War Election Programmes in 19 Democracies. Cambridge: Cambridge University Press. doi:10.1017/CBO9780511558771.002

Royed, T. J. (1996). Testing the Mandate Model in Britain and the United States: Evidence from the Reagan and Thatcher Eras. British Journal of Political Science, 26(1), 45-80. doi:10.1017/S0007123400007419

Schermann, K., \& Ennser-Jedenastik, L. (2012). Explaining coalition-bargaining outcomes. Party Politics, 20(5), 791-801. doi:10.1177/1354068812453373

Stegmaier, M., \& Vlachová, K. (2011). The parliamentary election in the Czech Republic, May 2010. Electoral Studies, 30(1), 238-241.

doi: 10.1016/j.electstud.2011.01.004

Strom, K. (1990). A Behavioral Theory of Competitive Political Parties. American Journal of Political Science, 34(2), 565-598. doi:10.2307/2111461

Strøm, K. W., \& Nyblade, B. (2009). Coalition Theory and Government Formation. Oxford Handbooks Online. doi:10.1093/oxfordhb/9780199566020.003.0032

Strøm, K., \& Müller, W. C. (1999). The keys to togetherness: Coalition agreements in parliamentary democracies. The Journal of Legislative Studies, 5(3-4), 255-282. doi:10.1080/13572339908420604 
Strom, K., Budge, I., \& Laver, M. J. (1994). Constraints on Cabinet Formation in Parliamentary Democracies. American Journal of Political Science, 38(2), 303335. doi:10.2307/2111406

Thies, M. F. (2001). Keeping Tabs on Partners: The Logic of Delegation in Coalition Governments. American Journal of Political Science, 45(3), 580-598. doi: $10.2307 / 2669240$

Thomson, R., Royed, T., Naurin, E., Artés, J., Costello, R., Ennser-Jedenastik, L., et al. (2017). The Fulfillment of Parties' Election Pledges: A Comparative Study on the Impact of Power Sharing. American Journal of Political Science, 61(3), 527-542. doi:10.1111/ajps.12313

Volejnikova, J. (2005). A modern compendium of economic theories: from ancient sources to the third millennium. Prague: Profess Consulting.

Warwick, P. V. (1996). Coalition Government Membership in West European Parliamentary Democracies. British Journal of Political Science, 26(4), 471-499. doi.org/10.1017/S0007123400007572

Wolinetz, S. B. (2002). Beyond the Catch-All Party: Approaches to the Study of Parties and Party Organization in Contemporary Democracies (pp. 136-165.). In Wiarda, H. J. (ed.) Comparative Politics. Critical Concepts in Political Science. London: Routledge.

Zubek, R., \& Klüver, H. (2013). Legislative pledges and coalition government. Party Politics, 21(4), 603-614. doi:10.1177/1354068813487126 